\title{
AZ IGAZSÁGOSSÁGKUTATÁS, AZ EGYÜTTMÜKÖDÉS- VERSENGÉSKUTATÁS ÉS A HATALOM PSZICHOLÓGIÁJÁRA IRÁNYULÓ KUTATÁS TEMATIKUS ÉRINTKEZÉSI PONTJAI
}

\author{
KOVÁCS JUDIT
}

DE BTK Pszichológiai Intézet, Szociál- és Munkapszichológiai Tanszék

E-mail: kovacs.judit@arts.unideb.hu

Beérkezett: 2014. október 10. - Elfogadva: 2014. december 20.

\begin{abstract}
A tanulmány az eredmény, a folyamat és a kapcsolatok idői kiterjedésének a szempontjai segítségével veti össze az igazságosságkutatásnak, az együttmüködés-versengéskutatásnak és a hatalomgyakorlás kutatásának néhány meghatározó eredményét. Rámutat arra a mindhárom kutatási területen jelentkezó összefüggésre, hogy a hosszú idöperspektívával rendelkezö kapcsolatokban a normatartó folyamatelemeket hordozó viselkedés az eredményes, úgy egyénileg, mint közösségi szinten. A tanulmány elemzi a kutatási stratégiák különbözőségét (strukturális, csereelméleti alapokon nyugvó viselkedéses kutatások versus kérdöívben történö önbeszámolók, illetve reprezentációkat, asszociációkat vizsgáló kutatások), s amellett érvel, hogy a különbözö kutatási stratégiákat követö fölfogásoknak érdemes egymásban olyan partnereket látnia, akik a jelenség minél teljesebb megértéséhez visznek közel.
\end{abstract}

Kulcsszavak: disztributív és procedurális igazságosság, versengés, együttmüködés, hatalom, normatartás, rövid és hosszú távú kapcsolatok

\section{BEVEZETŐ}

A tanulmányban az igazságosság, a versengés és a hatalom pszichológiáját erősen kapcsolódó területeknek mutatom be a pszichológiai kutatásokban, noha mindhárom nagy témának megvan a maga szakirodalmi beágyazottsága, mely a másik két területre inkább érintőlegesen reflektál. A kapcsolódás lényege, hogy végső soron mindhárom terület köthető a jellemzően szűkös erőforrásokkal való bánásmód- 
hoz, azok elosztásához, megszerzéséhez, illetve megtartásához. Az igazságosságkutatás fő kérdése, hogy az emberek hogyan látják a vezetőik, illetve az általában vett följebbvalóik által meghozott elosztási döntéseket. A hatalomgyakorlás kutatásának is fontos kérdése, hogy hogyan hoznak a vezetők az erőforrások elosztásáról döntéseket. A versengés kutatásának szintén fontos tárgya, hogy milyen módon kerülnek az emberek a bőségesebb erőforrásokat birtoklók pozíciójába. Természetesen e kutatási területek e közös tárgyon túl specifikus témákat is magukban foglalnak. Ízelítőképp csak néhányat említünk meg: Például az átélt igazságtalanság következményeinek (például GREENBERG, 2004) nem sok átfedése van a hatalom témájával, de még mindig marad közös metszete a versengésével, amennyiben a győzelem és a vesztés pszichológiai következményeire (például SAPOLSKY, 2005; WILSON és KERR, 1999) vagy a rosszhír-keltés destruktív viselkedésválasztására gondolunk (SKARLICKI és FOLGER, 1997). Hasonló specifikus témák például a vezetőkről kialakult sztereotípiák (például KoENig, EAGLY, Mitchell és RISTIKARI, 2011) vagy a versengés személyiségpszichológiai háttere (például Ryckman, Libby, VAN den Borne, Gold és Lindner, 1997; Ross, RaUSCH és CANADA, 2003).

Figyelmünket e tanulmányban az erőforrás-elosztás rendező elvére fordítjuk, s az igazságosságkutatásban alkalmazott szempontrendszer analógiájára a versengés és a hatalom témáinak kapcsán is bemutatjuk, hogy az egyes területeken az eredmény, a folyamat és az időperspektíva szempontjai milyen ismereteket füznek fel. A tanulmány összefoglalójában az egyes területek tárgyalásából megismert összecsengő megállapításokat emeljük ki.

A három téma kutatásában nemcsak a közös tárgyat találhatjuk meg, de a kutatási stratégiáknak a hasonlóságát is. Az erőforrás-megosztás kapcsán megfigyelhető jelenségeket ugyanis lehet vizsgálni úgy is, hogy a tényleges erőforrás-elosztó, -megosztó helyzetekben megmutatkozó döntéseket és viselkedéseket tekintjük, és lehet beszámolt viselkedést, érzést, reprezentációt is vizsgálni, jellemzően vagy egy konkrét korábbi versengő, alárendelt vagy fölérendelt élettapasztalatot elbeszéltetve, arra visszaemlékezve, vagy általában véve a tárgykörben megélt tapasztalatokra gondolva. A tényleges viselkedést vizsgáló kutatási stratégiák előnye abban mutatkozik meg, hogy a jelenségeket a maguk viselkedéses szintjén pontos strukturális alapokon tudják megragadni, az emberi viszonyokban a jutalomfüggőségek különböző minőségeit megkülönböztetve. A beszámolókat, reprezentációkat vizsgáló kutatás előnye pedig abban áll, hogy valóságos viszonyokban megtörtént valódi események reprezentációit vizsgálva a megélt élményekhez visz közel. A megvitatásban annak is hangot adunk, hogy a különböző kutatási stratégiákat követő fölfogásoknak érdemes egyrészt a saját maguk erősségeivel és gyengéivel is tisztában lennie, másrészt a másik felfogáséval is, s egymásban olyan partnereket látni, akik a jelenség minél teljesebb megértéséhez visznek közel. 


\title{
EREDMÉNY ÉS FOLYAMAT A HÁROM TÉMÁBAN
}

\author{
Eredmény és folyamat az igazságosságkutatásban
}

Az eredménycentrikus igazságosságfölfogás

Az igazságosságkutatás azt vizsgálja, hogy az érintettek milyen feltételek mellett látják a jutalmak és a terhek elosztását igazságosnak. A kutatás első évtizedeiben az igazságosság kérdéseit eredménycentrikus módon fogalmazta meg a szociálpszichológia (DEUTSCH, 1975; HOMANS, 1958; WALSTER, WALSTER és BERSCHEID, 1978). A társas cserekapcsolatokban, ha összehasonlítjuk magunkat másokkal, a befektetések és a jutalmak milyen aránya tekinthető igazságosnak? Mi történik akkor, ha valaki arra a megállapításra jut, hogy igazságtalan részt kap a javakból vagy terhekből? Jár-e rossz érzéssel, ha kedvezményezettjei vagyunk az igazságtalan osztásnak? Különböző elosztási elvek szerint történő elosztás milyen társas célokhoz illik leginkább?

A kutatás e kezdő évtizedei nagyon sok fontos tapasztalatot fölhalmoztak (öszszefoglalót lásd például KovÁcs, 2014). Például, hogy az igazságtalanságnak következményei vannak (GREENBERG, 1982), hogy az igazságtalanság helyreállításáért áldozatokat is készek vagyunk hozni (GÜTH, SCHMITTBERGER és SCHWARze, 1982), vagy hogy más és más típusú kapcsolatokban más és más elosztási elvek szolgálnak az igazságosság mércéjéül (DEUTSCH, 1975). De számos kérdés megválaszolatlanul maradt. Köztük az egyik legfontosabb, hogy hogyan tud az igazságosság egy társas kohéziót szolgáló normaként működni, ha az emberekre általánosan jellemző, hogy egocentrikusan elfogultak, ami ebben az összefüggésben azt jelenti, hogy mindig azt az elosztási elvet látják helyénvalóbbnak, amivel aktuálisan ők maguk jobban járnának. Teszik ezt azért, mert saját teljesítményüket nagyobbnak látják, mint másokét (MESsick és SENTIS, 1979), illetve fontosabbnak látják, mint másokét (például DiekManN, SAMUEls, Ross és BAZERMAN, 1997). Másik ilyen kérdés, melyet csak az eredményeket tekintve nehéz megérteni, hogy az emberek sokszor miért tiltakoznak számukra kívánatos és egyetértésükre okot adó döntések miatt (GREENBERG, 2004).

\section{A folyamat szempontja az igazságosságkutatásban}

Ezekre a kérdésekre választ a procedurális igazságosság jelentőségének a felismerése adott, mely az elosztási döntések kivitelezésének és kommunikációjának a hogyanjára vonatkozik. Többen megkülönböztetik a döntési forgatókönyvek követéséhez kapcsolódó aspektust (proceduralitás) és a társas-viselekedéses aspektust (interaktivitás) (BIES és MOAG, 1986).

A helyes eljárások és az alapvető emberi tiszteletadás ugyanis nem szükös erőforrások. Attól függetlenül megillethetik az érintetteket, hogy a döntéshozók aktuálisan milyen eredményre jutnak, így az eredményt esetleg elégedetlenséggel fogadó felet is megnyugvással töltheti el az érzés, hogy az eredmény egy jó folyamatban született, és azt megfelelő stílusban közvetítették. Olyanban, amely többek 
között pontos információkon nyugodott, konzisztens és részrehajlás nélküli volt, garantálta a felek érdekképviseletét, az eredményt tekintve pedig korrigálhatónak bizonyult, ha új információk birtokában kiderült, hogy a korrigálás szükséges, és általában véve nem sértett etikai szabályokat (LEVENTHAL, 1980).

Kezdetben a helyes eljárásokat egyenesen a jó döntések feltételeként azonosították, és a helyes eljáráshoz (például a véleménynyilvánítási lehetőség megadása) való ragaszkodásban pusztán csak az érdekérvényesités motívumát látták (FOLGER, Rosenfield, Grove és Corkran, 1979; Thibaut és Walker, 1975). Később világossá vált, hogy a jó eljárások társas normájához, és általában véve az igazságossághoz, a társas kötelékek szilárdításának vágya által motiválva is ragaszkodunk. Ha nem tartják be az emberrel szemben azokat az alapvető normákat, melyek betartása csak a jóindulaton múlik, annak negatív jelentése van abból a szempontból, hogy az ember tényleg a csoport értékes tagjának számít-e a más csoporttagok szemében (Lind és TYLER, 1988; TYLER és Blader, 2003). Pontosan ezért ragaszkodnak az emberek a folyamatok igazságosságához, még akkor is, ha egyébként aktuálisan egy elosztási döntés eredményével szemben nincs semmiféle kifogásuk. A kötelékek, a társas kapcsolatok időben kiterjedéssel bíró vonatkozások, csakúgy, mint ahogyan az eljárások, folyamatok is implikálják az időbeli kiterjesztést. Tehát az időperspektíva beemelése az igazságosság tárgyalásába elkerülhetetlennek mutatkozik.

A bevezetőben említettük, hogy a tanulmányunkban kezelt mindhárom téma kutatásának van strukturális alapokon nyugvó, illetve önbeszámolós eljárásokkal adatokat gyűjtő hagyománya. A strukturális beágyazottságú korábbi kutatások inkább köthetők az eredményhangsúlyos szemlélethez, a későbbi önbeszámolós, illetve kérdőíves kutatások pedig inkább a procedúra-hangsúlyoshoz. A modern integratív modellek azonban az eredmény és a folyamat szempontjait együtt kezelik (Folger és Cropanzano, 2001; GreenberG, 2004). Még Tyler (2012) is, aki az 1980-as évek végétől hosszú évtizedeken át volt képviselője az igazságosságélményben a procedúrák elsődleges fontosságát hangsúlyozó és a társas funkciót a hatékonycsere-funkció elé helyező szemléletnek, az igazságosságkutatás történetéről 2012-ben írt összefoglalójában úgy fogalmaz, hogy a „hangsúly helyzetfüggő”, ezzel mintegy implikálva azt is, hogy a helyzetek konkrét karakterisztikumait a vizsgálatokban is érdemes számon tartani.

\section{Eredmény és folyamat a versengés kutatásában}

Az erőforrások megosztása természetesen nemcsak a hierarchikus kapcsolatokban jut el valamilyen folyamatot követve valamilyen eredményhez, hanem a mellérendelt kapcsolatokban történő versengés során is. A versengésre vonatkozóan is föl lehet tenni például azt a fontos kérdést, hogy miért, mikor, hogyan tudja a vesztes elfogadni státuszát, anélkül hogy a vetélytárssal kapcsolatban erős negatív indulatot érezne? E kérdésre a választ ugyanúgy a fair play versengés lehetösége és a fair playt követő gyakorlat adhatja meg, mint az igazságosság esetén a vezető által követhető igazságos procedúrák lehetősége és az igazságos procedúrák tényleges 
választása (FÜlÖP, 2008a; FÜlÖP és TAKÁCS, 2013; TJOSVOLD, JOHNSON, JOHNSON és Sun, 2006). A versengés kontextusában is ez rendezi a vesztes nyugtalanságát, és tartja benn a társas alakzatban, legyen szó egy interperszonális, egy szervezeti vagy egy társadalmi kapcsolatról (FÜLÖP, 2008b).

A versengéskutatásnak két nagy hagyománya van. A csereelméleti bázison nyugvó, a függési viszonyok struktúrájával számoló eredményorientált hagyománya (például De Dreu, Weingart és KwON, 2000; Kelley és Thibaut, 1978; Messick és MCCLinTOCK, 1968; VAN LANGE, 2012) és a versengéssel kapcsolatos reprezentációkat, és a versengés során átélt érzéseket vizsgáló hagyomány (például FÜlÖP, 2004; FÜlÖP, ROLAND-LeVY és BERKICS, 2004; RYCKMAN és mtsai, 1997). Az eredmény és a folyamat szempontjai mindkettőben értelmezhetőek.

\section{Az eredménycentrikus versengésfölfogás}

Az eredménycentrikus versengésfölfogás a versengést az alapján tekinti, hogy a versengés végeredménye kinek mennyi jutalmat hoz, értve ezen az általában vett erőforrásokból való részesedés mértékét. A versengést a függési viszonyok két teljesen különböző osztályában (GÄCHTER, 2004) indokolt értelmezni: az érdekkonfliktusokban és a vegyes motívumú helyzetekben.

\section{A konfliktus modell}

Egy valódi érdekkonfliktusban a versengés, vagyis a saját érdek követése az egyetlen eredményes stratégia, a másik érdekének a tekintetbevétele a biztos bukással egyenlő. A csatár egy kiélezett küzdelemben nem foglalkozhat azzal, hogy a kapusnak milyen rossz érzés lesz gólt kapni. Van persze az életben számos olyan helyzet is, mely csak első látásra tűnik valódi érdekkonfliktusnak, közelebbről és kreatívan tekintve a problémára, az ütköző érdekek összehangolhatóak. Az ilyen transzformálható helyzetekben saját maga számára is eredményesebb lehet, ha valaki nemcsak a saját érdekével, hanem a másik érdekével is foglalkozik (DE Dreu és mtsai, 2000; PruitT és Rubin, 1986).

A valódi érdekkonfliktusos helyzetek hozta versengést sokáig olyannak látta a szakirodalom, mint ami szükségszerúen árt az emberi kapcsolatoknak. DEUTSCH 1949-es dolgozatában (1981) a „versengő instrukciók” feladatvégző csoportokra mért negatív csoportdinamikai hatásáról írt. A csoportközi konfliktusok vonatkozásában Sherif és munkatársai az előítéletek érdekkonfliktus-elméletével (SHERIF, 1958) és az azt alátámasztó cserkésztáboros terepkísérletükkel is azt a nézetet erősítették, hogy a versengés gyülöletet szül. Nemcsak távoli társadalmi csoportok közt, de még barátok között is. Így alapozta meg az érdekkonfliktusok kezdeti kutatása a versengés dichotomizáló fölfogását, melyben a versengést az örök rosszként állította szembe a kooperációval mint örök jóval („,a szépség és a szörnyeteg” paradigmája, FÜLÖP, 2008c).

Az ilyen típusú szembeállítás azonban leegyszerűsítő. Egyrészt azért, mert a saját érdeket és a másik érdekét számos esetben egyszerre is szem előtt lehet tartani, másrészt azért, mert még a kooperációra lehetőséget nem adó, valódi konfliktusos 
helyzetekben sem szükségszerű a gyülölködés, ott is lehet korrekt kapcsolatot ápolni, gondoljunk csak a sportolók fair play küzdelmeire és az olimpiai mozgalom eszmeiségére.

Noha a konfliktusok érdekkonfliktus-elmélete megadta ezt a dichotomizáló alaphangot a vonatkozó tudományos és társadalmi vélekedésekhez, az érdekek összehangolásának gondolatával azt a kutatási vonulatot is megalapozta, mely az eredményorientált fölfogáson belül két dimenzióról, a saját érdek követéséről és a másik érdekének tekintetbevételéről beszél. A PRUITT és RUBIN (1986) által fölvázolt kettős érdek modell, melyet a kutatás legföképpen az érdekkonfliktusos, de érdekek integrálására lehetőséget kínáló tárgyalások tanulmányozásában használ, struktúrájában jól megjeleníti a két érdek tekintésének párhuzamos lehetőségét. DE DREU és munkatársai (2000) metaanalízise szerint az integratív tárgyalásokban valóban azok a személyek teljesítenek jól, akikben nemcsak a saját érdek érvényesítésének motívuma van meg (ezt ők „meg nem alkuvásnak” nevezik), de a másik szempontjaival való foglalkozás késztetettsége is.

Az érdekek összehangolásának lehetőségére egy másik elméleti vonulat is reflektál, de nem strukturális, hanem társas identitás alapon. A konfliktusok rendezésére és előítéletek föloldására kigondolt „újrakategorizáciơ” koncepciója (GAERTNER, MANN, MurRel és Dovidio, 1989) például azzal a logikával él, hogy a közös identitás az érdekkonfliktust az érdekazonosság látása felé tudja mozdítani azon a bázison, hogy a szélesebb alapú kategóriába vont másik által kapott jutalmat mint „saját" jutalmat tudja az ember tekinteni. A társas identitás gondolata, noha reflektál az érdekre, az anyagi érdek helyett sokkal inkább a presztízst érti érdek alatt, ilyen értelemben tanulmányunkban a társas kötelékeket hangsúlyozó folyamat, illetve hosszú idôtáv szakaszokba illik tárgyalásuk.

Versengés a vegyes motívumú helyzetekben

A vegyes motívumú helyzetek olyan struktúrájúak, hogy azokban az egyszeri viselkedésválasztás mozzanatában az együttműködés és versengés között szükségszerű dönteni. Nem azért, mert a vizsgálómodellek (például a fogolydilemma helyzet vagy a társas dilemmák) kényszerválasztásba terelik a válaszadót, hanem azért, mert az élet ilyen szerkezetű problémái választásokat tartalmaznak. Az más kérdés, hogy egy ismétlődő fogolydilemma helyzetben az együttmüködés lehet nagyon is eredményes (tehát a közös célok tekintése a saját célokhoz is közelebb visz). Messick és MCCLINTOCK (1968) specifikusan az ilyen vegyes motívumú helyzetek problémájára illesztve konceptualizálták a viselkedést bejósló egyéni tulajdonságként a társas értékorientációt, amely arra vonatkozik, hogy ha választani kell egy kölcsönös függésben a saját érdek és a másikat is tekintő együttes érdek között, akkor az egyén mit választ, vajon választása proszelf vagy proszociális orientációt tükröz-e.

Ez a koncepció és a hozzátartozó mérés azért állítja szembe az együttműködést és versengést, mert az élethelyzet, a viselkedésválasztás, amit a mérést alkalmazók be akarnak és be is tudnak (BALLIET, PARKS és JOIREMAN, 2009) a mérésben hozott döntés alapján jósolni, valóban maga is dichotóm. A társas értékorientáció koncepcióját a kutatás egy időben a vegyes motívumú helyzeteken túli érvényes- 
séggel is próbálta alkalmazni (például VAN LANGE, AGNEW, HARINCK és STEEMERS, 1997), mely gyakorlat érthető ellenérzéseket is kiváltott, és valószínűleg hozzájárulhatott a társas értékorientáció koncepciójával szemben megfogalmazott fenntartásokhoz (például FülÖP, 2013).

Az együttműködés és a versengés a fogolydilemma helyzetben és a társas dilemmákban tehát szembe van állítva csakúgy, mint a proszociális és proszelf társas értékorientáció. Azonban azt is érdemes látnunk, hogy egy olyan kontextusban van szembeállítva, ahol a versengés és az együttműködés valóban nem fér össze.

Ha az együttműködésnek a kívánatossal, a versengésnek pedig a nemkívánatossal való azonosításán a szakmai és a hétköznapi véleményalkotás mindig is csak azt értette volna, hogy a társas dilemmákban keresni kell a minél erősebb együttműködést, a „szépség és szörnyeteg” paradigmát moralizáló különbségtevése miatt valószínủleg kevesebb kritika érte volna.

\section{A folyamat szempontja az eredményorientált versengéskutatásban}

A konfliktus modell

A versengés érdekkonfliktus-elmélet általi tárgyalásában a versengés tehát hosszú ideig egyet jelentett a negatív interperszonális viszonyokkal. Személyközi szinten ezt jól demonstrálja DEUTSCH klasszikus vizsgálata (1949), csoportszinten pedig SHERIF nyári táboros terepkísérleteiről való beszámolók (1958), amelyek szerint az érdekkonfliktus és a versengés olyan negatív folyamatokat indít be, amely előítéletet és diszkriminációt eredményez.

Azt, hogy a versengésnek a csoportfolyamatokra általában és összességében negatív a hatása, anélkül hogy tekintettel lennénk a versengést jellemző specifikus karakterisztikumokra, például arra, hogy az mennyire szabálytartó vagy mennyire konstruktív, nem jelenthetjük ki (FüLÖP, 2004; FüLÖP és TAKÁCS, 2013).

Ugyanakkor vannak, akik a versengés jellemző (tehát nem kizárólagos) korrelátumának mégis a negatív interperszonális viszonyok generálását tartják. Ezt az álláspontot veszi fel a több szempontos, integratív potenciállal rendelkező tárgyalásokat elemző szakirodalom. A kutatás a kommunikációs folyamatban megjelenő negatív megjegyzéseket például a versengő (disztributív) tárgyalási stílus jegyei között tartja számon, az érvelő információközlés és az egy szempontos ajánlatok jegyei mellett. A disztributív tárgyaló nincs tekintettel az alkutér integratív potenciáljára, arra, hogy az ütköző érdekeket össze lehet a prioritások értelmes figyelembevételével valamelyest hangolni. Ehhez képest a pozitív érzelmi megnyilvánulásokat (a prioritásokra vonatkozó információközlés és a több szempontos ajánlat mellett) az integratív, vagyis a saját érdekkel és a másik érdekével egyaránt foglalkozó tárgyalási stílus jegyeként azonosítják. Az integrációt szokták még problémamegoldásnak is nevezni, de az sem ritka, hogy együttműködésként jelenik meg bizonyos interpretációkban. A pozitív társas klíma stimulálása tehát az érdekeket összeegyeztető tárgyalási stílus karakterjegye (lásd például PRUITT, 1981; SCHEI, Rognes és Shapiro, 2011; Weingart, Brett, Olekalns és SMith, 2007; Weingart, THOMPSOn, BAZERMAN és CARroll, 1990). Úgy tűnik, hogy ha foglalkozunk a másik érdekével, akkor ezzel együtt azt barátságosabban is tesszük. 
A csoportokon belüli konfliktusok hasznosságáról és ártalmasságáról folyó szakirodalmi vitában szintén fölbukkan a gondolat, hogy ha mindent mérlegre teszünk, a konfliktusok inkább ártanak a csoportklímának és csoportteljesítménynek, s nem használnak. DE DREU és WEINGART (2003) legalább is metaanalízisükben erre jutottak. Az, hogy ez a kérdés nem egyértelmü kérdésként merült föl, önmagában is demonstrálja, hogy a versengés, a konfliktus nem mindig ártalmas. Ugyanis az is igaz, hogy a szemléletek sokszínűsége, feltéve, hogy a különbözőségnek nincs semmiféle csoportdinamikai jelentése, általában javít a feladatmegoldás színvonalán (lásd például GRUBER, 2006). Továbbá a kohézív csoportokban kialakuló feladatkonfliktus javíthatja a feladatmegoldás színvonalát (SıMONS és PETERSON, 2000), feltéve, hogy a feladatkonfliktus nem csap át személyeskedésbe. Megfelelő bizalom és összetartás nélkül azonban ez elég könnyen megtörténhet.

Fontos azonban, hogy pusztán azért, mert a konfliktusok gyakran generálnak negatív indulatokat, mindezt ne tekintsük szükségszerủnek, s a közös identitás, valamint a fair play szabályainak tudatosítása, azok követésének számonkérése elejét tudja venni a negatív folyamatoknak.

Folyamat a vegyes motívumú helyzetekben

A vegyes motívumú helyzeteket a kutatás jellemzően face-to-face kommunikációt nem megengedő helyzetekben vizsgálja, olyan döntési helyzetekben, ahol a döntéshozó egy döntési mozzanatban beállítja a versengés és együttmüködés komplementer fokozatait. Van, amikor egészlegesen választ, de számos olyan paradigma is létezik, ahol az együttműködés fokozatai között választ.

Ezekben a vizsgálóhelyzetekben a folyamat szempontja elég limitáltan értelmezhető. A választások időbeli mintázatát tekintve kétszemélyes helyzetekben az együttműködést is és versengést is viszonzó, normatartó stratégia kapott folyamatelemként kitüntetett figyelmet. A viszonzó viselkedés normatartó folyamatelemként segíteni tudja a kölcsönösen nyereséges együttműködés kialakulását (például AXElROD, 1984; FALK, GäCHTER és KOVÁCS, 1999).

Mivel a vegyes motívumú helyzetek, a társas dilemmák vizsgálatában a kutatás a nagyobb kontroll kedvéért kerüli a face-to-face interakciókat és a verbális kommunikációt, így a folyamatoknak a viszonzáson, alkalmazkodáson túl elég kevés eleme értékelhető. Kevés kivétel viszont mégis lehetővé teszi a kommunikációt. Ezekből a vizsgálatokból az ígéretek melletti elkötelezödés mint normatív folyamatelem jelentősége derül ki (SAMUELSON és WATROUS-RODRIGUEZ, 2010), amely szintén erősíti a társas kötelékeket, s kedvező irányban befolyásolja a társas dilemmákban amúgy hanyatló közösségi áldozatvállalási folyamatot.

Összességében tehát az összetartást segítő (pozitív, együttműködő!) folyamatok segítik az együttműködő eredményt, ami a saját érdeket is szolgálja. Tehát ebben a kutatási vonulatban is van egy rendezés az együttműködő folyamat és együttműködő eredmény között. 
Eredmény és folyamat a versengéssel kapcsolatos reprezentációkat és metaattitűdöket vizsgáló kutatási hagyományban

Az együttműködés és versengés vizsgálatának nemcsak a tényleges viselkedést a maga strukturális bázisán megragadó csereelméleti alapokon nyugvó jutalomorientált hagyománya létezik tehát, hanem az is, mely a versengéssel kapcsolatos vélekedéseket és metaattitűdöket, illetve a versengés tárgyú spontán asszociációkat és reprezentációkat vizsgálja (lásd például FÜLÖP, 2004; FüLÖP és mtsai, 2004; RYCKMAN és mtsai, 1997).

Ezek a kutatások az együttműködést és a versengést egyrészt a személyiség motivációs bázisára alapozva, másrészt a laikus tapasztalatok és arról való beszámolók szerveződése alapján nem dichotóm módon, hanem két egymástól független, de egymással különböző kombinációkat képezhető jelenségként fogják fel (például FÜLÖP, 2008; VAN DE VLIERT, 1999).

A laikus tapasztalatok, beszámolók, reprezentációk is megkülönböztetik a versengés eredményét (győzzelem és vesztés) és a versengés folyamatát (például tisztességes versengés, önfejlesztő versengés). FüLÖP Márta és TAKÁCs Szabolcs (2013) tanulmányukban az együttmúködéssel, illetve bizalommal teli, illetve az együttműködést és bizalmat nélkülöző versengés példáit vetik össze, amelyeket diákok és oktatók idéztek föl. (Jelen tanulmányunk kontextusába helyezve az együttműködés és bizalom, a maguk meghatározó viselkedéses következményeivel a folyamat jellemzői, a versengés pedig az eredmény szempontjából értelmezett konfliktusos kölcsönös függés.) A kooperatív versengést élvezhetőbbnek, inspirálóbbnak és méltányosabbnak találták. Az egyértelmű és átlátható szabályok hozzájárulnak ahhoz, hogy a versengés élvezetesebb legyen, és inspirálóbb is. A kooperatív, bizalommal teli versengés nem okoz negatív stresszt, hiányzik belőle a manipuláció és ármánykodás, és segíti a felek közötti kapcsolat megmaradását és fejlődését.

Az eredmény és folyamat súlyát illetően persze léteznek hangsúlyeltolódások, akár kulturális szinten is. Magyarországon például inkább az eredményre összpontosítanak az emberek, és a versengéshez negatív érzelmek tapadnak. Az együttműködés és versengés összeegyeztetése a versengésről folyamatában gondolkozó kultúrákban hosszú távon jelenik meg: a vetélytárs megőrizendő kapcsolat, akivel a szabályos verseny segíti a fejlesztést, fejlődést (lásd például FÜLÖP, 2004).

Tehát a versengésről szóló reprezentációs kutatás számos esetben a versengés olyan jelentésrétegére mutatott rá, amely a társas kötelékek építésében való együttműködésre vonatkozott (kapcsolat, fair play). Felvetődik a kérdés, vajon ez az együttműködés jelentését, lényegét tekintve nem feleltethető-e meg, nem analóg-e a procedurális igazságosság társas lényegével, a rendben lévő, összetartást erősítő, szabályos folyamatokkal, amelyek segítik a hosszú távú hatékonyságot, még akkor is, ha esetleg aktuálisan a személy vesztett? 


\section{Eredmény és folyamat a hatalom (vezetés) kutatásában}

A hatalom egyik ma népszerű, minimalista definíciója maga is eredményorientált: kontroll mások jutalmai fölött (FISKE és BERDAHL, 2007; PÁNTYA és KovÁCS, 2014). A hatalom működésére irányuló kutatások szép száma követi azonban a hatalom emlékeztetőivel való, a jutalomelosztás konkrét mozzanatát kikerülő elóhangolás gyakorlatát is. Ezekben a vizsgálatokban a hatalmat - és annak hatását, például az implicit attitűdökre - nem az alany saját rendelkezésére bocsátott valós erőforrások (például pénz) segítségével ragadják meg, hanem úgy, hogy olyan élethelyzeteket képzeltetnek el vele, vagy olyan szituációkat idéztetnek föl vele saját emlékeiből, amelyekben befolyása volt mások sorsára (GUINOTE, WiLLIS és MARTELLOTTA, 2010). Vagyis a strukturális és a reprezentációs felfogás kettőssége ezen a területen is jelen van.

A folyamatról, vagyis a hatalomgyakorlás stílusáról (például vezetési stílus), elöljáróban jegyezzünk meg annyit, hogy ennek a klasszikus szociálpszichológiai kérdéskörnek a kimerítő tárgyalása kívül esik e tanulmány hatókörén.

Ezzel szemben, eddigi gyakorlatunknak megfelelően, azokra a folyamatelemekre kellene figyelmünket fordítani, melyek megakadályozzák a hatalommal való visszaélést. Mindkét korábbi témában arról volt ugyanis szó a folyamat kapcsán, hogy mik azok a társas egység fennmaradása szempontjából kötelékeket erősítő, kapcsolatokat stabilizáló folyamatelemek, amelyek még rossz eredmény esetén is be tudják tölteni a társas összetartozást erősítő funkciójukat, és ezzel segíteni tudják a csoportos létezés (az együttműködés) folytatását.

Az immorális hatalomhasználatot kivédi például a hatalom társas kiérdemeltsége (például FAST és CHEN, 2009), a hatalomgyakorlás közegének transzparenciája (például Roth és MALOUF, 1979), az elosztásban érintettek beleszólási és döntési joggal való felruházása (például GüTH és mtsai, 1982; Kovács, 2014). Többek között ezek a folyamatjellemzők segítik az időben stabil és közjót szolgáló hatalom fennmaradását. Ezek mellett a feltételek mellett elképzelhető a méltányos hatalomgyakorlás. De ezeken túl ide állíthatnánk mindazokat a folyamatelemeket még, melyeket az igazságosságkutatás egy másik nézőpontból, a hatalomgyakorlás hatását átélő érintett nézőpontjából azonosított (például BIES és MOAG, 1986; LEVENTHAL, 1980; TYLER, 1994).

A szakirodalom még a köztudatban oly sok negatív tulajdonsággal felruházott machiavellistákkal kapcsolatban is arról számol be például, hogy az elszámoltatás és számonkérhetőség feltétele mellett nagyon is méltányosak (CURRY, CHESTERS és VIDING, 2011; PÁNTYA, 2014), és ha fontos egy helyzetben számukra a társas elfogadottság, akkor normatartóak, például tartózkodnak a nemkívánatos társas befolyásolási praktikáktól (GRAMS és ROGERS, 1990). Bár a kísérletes vizsgálatok időperspektíváját alapul véve rövid távú és hosszú távú stratégiáikat saját maguk is megkülönböztetik (CZIBOR és BERECZKEI, 2010), értve ezen azt, hogy például társas dilemmával élő többkörös vizsgálati szituációban a benyomáskeltést inditásképp emlegetik, hogy annak hasznát a folyamat vége felé learassák, vannak olyan beszámolók is, melyek szerint a machiavellisták akár igen hosszú távon is tudnak 
kifejezetten normatartóan és a közösséget építően viselkedni. Így például az amerikai elnökökre visszatekintve, az amerikaiak azokat az elnököket vélik a legjobban teljesítónek és legkarizmatikusabbnak, akiket egyben a legmachiavellistábbnak is gondolnak (DELUGA, 2001).

\section{AZ IDŐFAKTOR A HÁROM TÉMÁBAN}

A kapcsolatok időperspektívája mindhárom vonatkozásban, az igazságosság, a versengés és a hatalom témájában is kulcsfontosságú, ahogyan arra az eredmény és a folyamat szempontjainak tárgyalásakor is utaltunk. A folyamat a fogalom lényegéből adódóan olyasvalami, aminek az értelmezéséhez idői kiterjesztés kell. Az igazságossági élmény szerveződését két elmélet is, egymáshoz hasonlító módon, úgy írja le például, mint amelyet egy disztributív esemény indít, s a kiértékelés során a folyamatelemek gazdagítanak és töltenek meg igazi jelentéssel (Folger és Cropanzano, 2001; GreEnberG, 2004).

Ezzel együtt nem érdemes a folyamat fogalmát a hosszú távú vonatkozásokkal összemosni. Egyrészt mert minőségileg megkülönböztethető folyamatelemek rövid távú kapcsolatokban is vannak (például normatartás vagy normaszegés a viszonzás vagy a nem viszonzás formájában), másrészt mert a hosszú távú, stabil kapcsolatok sem feltétlenül csak normatartó, kapcsolatot stabilizáló folyamatelemeket tartalmazhatnak (mint például amilyen a tisztességes versenyzés). Hiszen a stabil kapcsolatok is destabilizálódhatnak, sokszor éppen valamilyen normasértő, a folyamatok és viselkedésmódok szempontjából aggályos cselekmény miatt (például egy házasság az egyik fél hütlensége miatt).

Persze számos elmélet és vizsgálat alapján a jó folyamatok és a hosszú távú, kölcsönösen gyümölcsöző, stabil kapcsolatok együtt járnak. Az igazságossági kiértékeléssel kapcsolatban MOORMAN (1991) például azt hangsúlyozza, hogy magas kohéziójú kapcsolatokban kevésbé követjük nyomon az egyes epizódok részletes elosztási egyensúlyát, figyelmünk inkább a könnyebben észlelhető társas és formai jegyek észlelésére irányul. Ezek a formai jegyek hosszú távú becslésekre alkalmasak. Alkalmazásuk - mivel kifogyni belőlük nem lehet - csak az alkalmazó szándékán múlik. Ez a szándék kifejezi a személynek az emberekhez általában véve, illetve specifikusan hozzánk való viszonyulását (VAN DEN BOS, 2001). Orvosokat műhibaperbe vonni is inkább a viselkedésük, mint a tényleges mulasztásaik miatt szoktak (LEVINSON, 1994), illetve a partnerkapcsolatok jövőjéről is nagyon informatív, hogy akár csak a leghétköznapibb témáról is egymás felé a tiszteletet megadva vagy nem megadva beszélgetnek (GOTTMAN, 1994).

Az idő a versengés jelenségének vizsgálatában is kulcsfontosságú dimenzió, legyen szó akár strukturális alapú, akár reprezentációs vizsgálatokról. Az együttműködő és versengő viselkedési stratégiák közötti választást vizsgáló társasdilemma-kutatások szerint, különösen kétszemélyes kapcsolatokban, az idő és az ismétlés kedvez a kölcsönösen jó együttműködések kialakulásának (például FALK és mtsai, 1999). A kapcsolatok mélyüléséhez szükséges idő integratív része az identitásalapú együttmüködésnek is, amely egy társas egységet a kölcsönös bizalom 
kapcsolati ereje által is együttműködőbbé és sikeresebbé tud tenni társasdilemmahelyzetben (KRAMER és BREWER, 1984).

A kapcsolatok időperspektívája a reprezentációs versengéskutatásoknak is szerves része. Fülöp Márta a magyarokat például kulturális összehasonlító vizsgálataiban több összevetésben is olyannak mutatja be, akár a franciákkal, akár a japánokkal való összehasonlításban, mint akik a versengésfogalmukban inkább az eredményre és nem a versengési folyamatra, inkább az egyénre és nem a társadalomra gondolnak (FÜLÖP, 2004; FÜLÖP és mtsai, 2004).

A vezetés és a hatalom vonatkozásában az idő dimenziója a hosszú távú beválás kapcsán szokott fölmerülni. Hogyan működik az a hatalom, mely sikeres és stabil, mely egyaránt sikerre viszi a csoportot, illetve az azt alkotó egyéneket? Ebben a kérdésben az igazságosság problematika komplementer megfogalmazását láthatjuk, és röviden úgy válaszolhatunk, hogy a vezetettekben az igazságosságélményt nyújtó hatalomnak jó esélye van a stabilitásra és a nyugodt építkezésre. Tegyük hozzá, ezt a megállapításunkat inkább az angolszász fölényű szakirodalom, illetve demokráciagyakorlat alapján tesszük, e tekintetben lehetnek és vannak is kulturális különbségek. Például egy amerikai-japán-kínai-dél-koreai összehasonlító vizsgálatból azt derült ki, hogy a folyamat szempontjai és az interaktív igazságosság valóban sokkal fontosabbak az amerikaiaknak, de a japánoknak is az általános igazságélményük formálásában, míg a kínaiaknak és koreaiaknak a disztributív igazságosság volt fontosabb (KIM és LEUNG, 2007).

\section{ÖSSZEFOGLALÁS}

Áttekintve az eredmény, a folyamat és az idő szempontjait az igazságosság-, a versengés- és a hatalomkutatáson, számos összecsengő megállapítást fogalmaztunk meg: Az elosztási döntésekben a normatartó, elő́rásoknak megfelelő és az emberi érintkezés alapvető szabályait betartó folyamatokat alkalmazó döntéshozók (hatalomgyakorlók, vezetők) erősítik a társas kohéziót, stabilizálják az egyének csoporthoz való kötődését, és attól függetlenül el tudják fogadtatni a vezetői döntések eredményét, hogy aktuálisan azok kedvezőek vagy éppen kedvezőtlenek az érintettek számára. A versengésben a társas kapcsolat fenntartását támogató folyamatok hosszú távon mind az egyén, mind a csoport (kapcsolat) érdekeit szolgálják, még akkor is, ha esetleg aktuálisan az egyén nem részesül a számára legkívánatosabb javakban (nem győz). Vagyis, amíg az ember társadalmi kötelékben él (márpedig egyedül feladatait megoldani nem tudja), hosszú távon a konstruktív módon történő önérdek-érvényesítés az eredményes, akármennyire is sikeres lehet egy destruktív, normaszegő módon történő önérdek-érvényesítés rövid távon. Ezzel párhuzamosan, a közös identitás nélküli, együttműködésre alkalmatlan helyzetekben az együttműködő viselkedési stílus eredményében alulmúlja a nem együttműködő stílust. (Például egy nem ismétléses, de szekvenciális fogolydilemma helyzetben az első lépést tevő együttműködését viszonzó - vagyis normatartó viselkedés eredményében alulmúlja a normaszegő nem viszonzást.) Vannak tehát olyan helyzetek, ahol az önérdek-képviselet és az együttmüködő stílus egymás ellentétei, és 
természetesen olyanok is, ahol összeegyeztethetöek. Ilyen helyzetek azok, amikor a kapcsolat maga fontos, mert idötávlata van.

Jelen dolgozatunkban a helyzeteknek az idői (kapcsolati) aspektus mentén való különválasztása példát szolgáltat arra, hogy egy általános jelenséget helyzetspecifikusan közelítsünk meg. Az elosztásreleváns helyzeteket természetesen az időn kívül még számos tényező alapján lehet specifikálni. Ilyen volt például dolgozatunkban az érintettek közötti kölcsönös függés természete (konfliktusos versus vegyes motívumú helyzetek). Ezek a pontosítások kényelmesebben megtehetők a strukturális bázisú megközelítésekben, akár kísérleti játékok alkalmazásával, de végső soron megtehetők (és szép számmal akadnak erre is példák) a kérdőíves kutatásokban is (például TJOSVOLD, 1988). Van viszont, ami a kísérletes vizsgálatokban nehezen megragadható, mindenképpen ilyen például a tartós, közös identitásalapú kapcsolat. Ennek az élmény közeli reprezentációnak a vizsgálatára alkalmasabbak a kérdőíves, illetve az asszociációkat, reprezentációkat vizsgáló kutatások. Nagyon fontosnak tartom, hogy a különböző megközelítésekkel, szemléletmódokkal jellemezhető kutatások vállalják fel a rájuk jellemző erényeket, legyenek tisztában a saját érzékeny pontjaikkal, és kölcsönösen méltányolják az övékétől eltérő megközelítésekben azokat az erényeket, amelyekben ők maguk szűkölködnek.

\section{IRODALOM}

Axelrod, R. (1984). The Evolution of Cooperation. New York: Basic Books.

Balliet, D., Parks, C., \& Joireman, J. (2009). Social value orientation and cooperation in social dilemmas: A meta-analysis. Group Processes \& Intergroup Relations, 12, 533-547.

BIES, R. I., \& MOAG, J. S. (1986). Interactional justice: Communication criteria of fairness. Research on Negotiation in Organizations, 1, 43-55.

Curry, O., Chesters, M. J., \& Viding, E. (2011). The psychopath's dilemma: The effects of psychopathic personality traits in one-shot games. Personality and Individual Differences, 50, 804-809.

Czibor A. és BereCzKei T. (2010). Ki nyeri meg a versenyt? Egy kompetitív kísérleti játék tanulságai. Magyar Pszichológiai Szemle, 65(1), 165-182.

De Dreu, C. K. W., Weingart, L. R., \& KwON, S. (2000). Influence of social motives on integrative negotiations: A meta-analytic review and test of two theories. Journal of Personality and Social Psychology, 78, 889-905.

De Dreu, C. K., \& WeingaRT, L. R. (2003). Task versus relationship conflict, team performance, and team member satisfaction: a meta-analysis. Journal of Applied Psychology, $88,741-749$.

DelugA, R. J. (2001). American presidential Machiavellianism: Implications for charismatic leadership and rated performance. The Leadership Quarterly, 12, 339-363.

Deutsch, M. (1975). Equity, equality, and need: What determines which value will be used as the basis of distributive justice?. Journal of Social Issues, 31, 137-149.

DeuTsCh, M. (1981). Az együttmüködés és a versengés hatása a csoportfolyamatokra. In CSEPELI GY. (szerk.), A kísérleti társadalomlélektan fóárama (239-275). Budapest: Gondo- 
lat. (Eredeti megjelenése: Deutsch, M. [1949]. An experimental study of the effects of co-operation and competition upon group process. Human Relations, 2, 199-232.)

Diekmann, K. A., Samuels, S. M., Ross, L., \& Bazerman, M. H. (1997). Self interest and fairness in problems of resource allocation: Allocators Versus Recipients. Journal of Personality and Social Psychology, 72, 1061-1074.

FALK, A., GÄCHTER, S., \& KovÁCS, J. (1999). Intrinsic motivation and extrinsic incentives in a repeated game with incomplete contracts. Journal of Economic Psychology, 20, 251-284.

FAST, N. I., \& Chen, S. (2009). When the boss feels inadequate. Power, incompetence, and aggression. Psychological Science, 20, 1406-1413.

Fiske, S. T., \& Berdahl, J. (2007). Social power. In A. W. Kruglanski \& E. T. Higgins (Eds.), Social Psychology: Handbook of Basic Principles (678-692). New York: Guilford.

Folger, R., \& Cropanzano, R. (2001). Fairness theory: Justice as accountability. Advances in Organizational Justice, 1, 1-55.

Folger, R., Rosenfield, D., Grove, J., \& Corkran, L. (1979). Effects of "voice" and peer opinions on responses to inequity. Journal of Personality and Social Psychology, 37, 22532261.

FÜlÖP, M. (2004). Competition as a culturally constructed concept. In C. BAILLIE, E. Dunn, \& Y. Zheng (Eds.), Travelling Facts. The Social Construction, Distribution, and Accumulation of Knowledge (124-148). Frankfurt/New York, NY: Campus.

FÜLÖP M. (2008a). Verseny a társadalomban - verseny az iskolában. In BENEdEK A. és GLER D. (szerk.), VII. Nevelésügyi Kongresszus. Az oktatás közügy (51-74). Budapest: Magyar Pedagógiai Társaság.

FÜLÖP, M. (2008b). Educating the cooperative competitive citizen. In K. TIRRI (Ed.), Educating Moral Sensibilities in Urban Schools (171-187). Rotterdam: Sense Publishers.

FÜlÖP M. (2008c). Paradigmaváltás a versengéskutatásban. Pszichológia, 28, 113-140.

FüLÖP M. (2013). A versengés, a gyözelem és a vesztés pszichológiája és kulturális különbségei. Akadémiai Doktori Disszertáció.

FÜlÖP, M., ROLAND-LEVy, C., \& BERKICS, M. (2004). Economic competition perceived by French and Hungarian adolescents. In A. Ross (Ed.), The Experience of Citizenship (325331). London: London Metropolitan University.

FÜlÖP, M., \& TAKÁCS, Sz. (2013). The cooperative competitive citizen: what does it take? Citizenship, Teaching, Learning, 8(2), 131-156.

GÄCHTER, S. (2004). Behavioral game theory. In D. J. Koehler, \& N. HARvey (Eds.), Blackwell Handbook of Judgment and Decision Making (485-503). Oxford: Blackwell Publishing.

Gaertner, S. L., Mann, I., Murrell, A., \& Dovidio, .J. F. (1989). Reducing intergroup bias: The benefits of recategorization. Journal of Personality and Social Psychology, 57, 239-249.

Gottman, I. M. (1994). What Predicts Divorce? The Relationship between Marital Processes and Marital Outcomes. Hillsdale, NJ: Erlbaum.

Grams, W. C., \& Rogers, R. W. (1990). Power and personality: Effects of Machiavellianism, Psychology, 117, 71-82.

GREENBERG, J. (1982). Approaching equity and avoiding inequity in groups and organizations. In J. GreenberG \& R. L. Cohen (Eds.), Equity and Justice in Social Behavior (389435). New York: Academic Press. 
GREENBERG, J. (2004). Stress fairness to fare no stress: Managing workplace stress by promoting organizational justice. Organizational Dynamics, 33, 352-365.

Gruber, H. E. (2006). Creativity and conflict resolution: The role of point of view. In M. Deutsch, \& P. T. Coleman (Eds.), The Handbook of Conflict Resolution: Theory and Practice (391-401). San Francisco: Jossey-Bass.

Guinote, A., Willis, G. B., \& Martellotta, C. (2010). Social power increases implicit prejudice. Journal of Experimental Social Psychology, 46, 299-307.

GÜTh, W., SChmittberger, R., \& SChwarze, B. (1982). An experimental analysis of ultimatum bargaining. Journal of Economic Behavior and Organization, 3, 367-388.

Homans, G. C. (1958). Social behavior as exchange. American Journal of Sociology, 63, 597606.

Kelley, H. H., \& Thibaut, J. W. (1978). Interpersonal Relations: A Theory of Interdependence. New York: Wiley.

KIM, T. Y., \& LEUnG, K. (2007). Forming and reacting to overall fairness: A cross-cultural comparison. Organizational Behavior and Human Decision Processes, 104(1), 83-95.

Koenig, A. M., Eagly, A. H., Mitchell, A. A., \& Ristikari, T. (2011). Are leader stereotypes masculine? A meta-analysis of three research paradigms. Psychological bulletin, 137, 616-642.

KovÁcS J. (2014). Az igazságosság és a hatékonyság az interperszonális és a társadalmi kapcsolatok pszichológiájában. Debrecen: Debreceni Egyetemi Kiadó.

Kramer, R. M., \& Brewer, M. B. (1984). Effects of group identity on resource use in a simulated commons dilemma. Journal of Personality and Social Psychology, 46, 1044-1057.

Leventhal, G. S. (1980). What should be done with equity theory? In K. Gergen, M. Greenberg, \& R. Willis (Eds.), Social Exchange (27-55). New York, NY: Plenum.

LeVinson, W. (1994). Physician-patient communication: a key to malpractice revention. Jama, 272, 1619-1620.

Lind, E. A., \& Tyler, T. R. (1988). The Social Psychology of Procedural Justice. New York: Plenum.

Messick, D. M., \& MCClintock, C. G. (1968). Motivational bases of choice in experimental games. Journal of Experimental Social Psychology, 4, 1-25.

Messick, D. M., \& SEnTis, K. P. (1979). Fairness and preference. Journal of Experimental Social Psychology, 15, 418-434.

Moorman, R. (1991). Relationship between organizational justice and organizational citizenship behaviors: Do fairness perceptions influence employee citizenship? Journal of Applied Psychology, 76, 845-855.

PÁNTYA J. (2014). Helyzetbe hozni vagy helyzetbe kerülni? A fölérendelt szerep, a machiavellizmus és a társas értékorientáció hatalmi viselkedést befolyásoló hatásainak kísérletes vizsgálata. PhD értekezés, Debrecen.

PÁNTYA J. és KovÁcS J. (2014). A hatalom pszichológiai következményei - A hatalmi előhangolást alkalmazó szociálpszichológiai kísérletek néhány tanulsága. In MÜNNICH Á. (szerk.), Pszichológiai kutatások - Debreceni Egyetem Pszichológiai Doktori Program (137-150). Debrecen: Debreceni Egyetemi Kiadó.

PruitT, D. G. (1981). Negotiation Behavior. New York: Academic Press.

Pruitt, D. G., \& Rubin, J. Z. (1986). Social Conflict: Escalation, Stalemate, and Settlement. New York: Random House. 
Ross, S. R., Rausch, M. K., \& CANADA, K. E. (2003). Competition and cooperation in the five-factor model: individual differences in achievement orientation. The Journal of Psychology, 137(4), 323-337.

Ross, A., Read, B., Kuscer, M. P., Fulop, M., Pucko, C., Berkics, M., Sandor, M., \& Hutchings, M. (2005). Teachers' constructions of citizenship and enterprise: Using associative group analysis with teachers in Hungary, Slovenia and England. New Educational Review, 7(3-4), 111-139.

Roth, A. E., \& Malouf, M. W. K. (1979). Game-theoretic models and the role of information in bargaining. Psychological Review, 86, 574-594.

Ryckman, R. M., Libby, C. R., van den Borne, B., Gold, I. A., \& Lindner, M. A. (1997). Values of hypercompetitive and personal development competitive individuals. Journal of Personality Assessment, 69, 271-283.

Samuelson, C. D., \& Watrous-Rodriguez, K. M. (2010). Group discussion and cooperation in social dilemmas: Does the medium matter? In R. M. Kramer, A. E. Tenbrunsel, \& M. H. Bazerman (Eds.), Social Decision Making - Social Dilemmas, social Values, and Ethical Judgments (13-46). New York: Psychology Press.

SAPOLSKY, R. M. (2005). The influence of social hierarchy on primate health. Science, 308(5722), 648-652.

SCHEI, V., Rognes, I. K., \& SHAPIRO, D. L. (2011). Can individualists and cooperators play together? The effect of mixed social motives in negotiations. Journal of Experimental Social Psychology, 47, 371-377.

SHERIF, M. (1958). Superordinate Goals in the Reduction of Intergroup Conflict. American Journal of Sociology, 43, 349-356.

Simons, T. L., \& Peterson, R. S. (2000). Task conflict and relationship conflict in top management teams: The pivotal role of intragroup trust. Journal of Applied Psychology, 85, $102-111$.

Skarlicki, D. P., \& Folger, R. (1997). Retaliation in the workplace: The roles of distributive, procedural, and interactional justice. Journal of Applied Psychology, 82, 434-443.

Thibaut, J., \& Walker, L. (1975). Procedural Justice: A Psychological Analysis. Hillsdale, NJ: Erlbaum.

TJosvold, D. (1988). Cooperative and competitive dynamics within and between organizational units. Human Relations, 41, 425-436.

TJosvold, D., Johnson, D. W., Johnson, R., \& Sun, H. (2006). Competitive motives and strategies in organizations: Understanding constructive interpersonal competition. Group Dynamics: Theory, Research, \& Practice, 10, 87-99.

TYler, T. R. (1994). Psychological models of the justice motive: Antecedents of distributive and procedural justice. Journal of Personality and Social Psychology, 67, 850-863.

Tyler, T. R. (2012). A history of justice and morality research. In A. W. P. Kruglanski, \& W. Stroebe (Eds.), Handbook of the History of Social Psychology (453-474). New York: Psychology Press.

Tyler, T. R., \& Blader, S. L. (2003). The group engagement model: Procedural justice, social identity, and cooperative behavior. Personality and Social Psychology Review, 7, 349361 .

VAN DE Vliert, E. (1999). Cooperation and competition as partners. European Review of Social Psychology, 10, 231-257. 
VAN DEN BOS, K. (2001). Uncertainty management: the influence of uncertainty salience on reactions to perceived procedural fairness. Journal of Personality and Social Psychology, 80, 931-941.

VAn LANGE, P. A. (2012). A history of interdependence: Theory and research. In A. W. P. Kruglanski, \& W. Stroebe (Eds.), Handbook of the History of Social Psychology (341-351). New York: Psychology Press.

Van Lange, P. A., Agnew, C. R., Harinck, F., \& Steemers, G. E. (1997). From game theory to real life: How social value orientation affects willingness to sacrifice in ongoing close relationships. Journal of Personality and Social Psychology, 73, 1330-1344.

Walster, E., Walster, G. W., \& Berscheid, E. (1978). Equity: Theory and Research. Boston: Allyn \& Bacon.

Weingart, L. R., Brett, J. M., Olekalns, M., \& Smith, P. L. (2007). Conflicting social motives in negotiating groups. Journal of Personality and Social Psychology, 93, 994-1010.

Weingart, L. R., Thompson, L. L., Bazerman, M. H., \& Carroll, J. S. (1990). Tactical behavior and negotiation outcomes. International Journal of Conflict Management, 1, 7-31.

Wilson, G. V., \& KerR, J. H. (1999). Affective responses to success and failure: A study of winning and losing in competitive rugby. Personality and Individual Differences, 27, 85-99.

\title{
OVERLAPS IN RESEARCH AREAS OF JUSTICE, COOPERATION/COMPETITION AND POWER
}

\author{
KOVÁCS, JUDIT
}

The paper compares some significant results from different research lines of literature on justice, on cooperation/ competition and on power. The aspects of result, process and time perspective are used for this comparison. In case of enduring, long term relationships the positive correlation between normkeeping cooperative behavior style and efficient individual and communal results is underpinned, which relationship unequivocally appears in all of the three research lines. The paper also pays attention to different research strategies (structural studies based on the theory of interdependence and researches studying associations, representations, metaattitudes) and argues for a careful and cooperative attitude in research, because each strategies have their own advantages and disadvantages.

Key words: distributive and procedural justice, competition, cooperation, power, norm-keeping, short and long term relationships 